\title{
FACTORS INFLUENCING THE ENTREPRENEURIAL BEHAVIOUR OF AGRICULTURAL GRADUATES
}

\author{
S. Chandrashekar ${ }^{1}$, R. Bahal ${ }^{2}$ and V. P. H. $\mathbf{D}^{3}$ \\ ${ }^{1}$ Programme Coordinator, Krishi Vigyan Kendra (KVK), PALEM, Andhra Pradesh, India.
}

\begin{abstract}
The study is to assess the performance of Agri Clinic entrepreneurs promoted under the scheme on Agri Clinic and Agri Business Centers in India. Thus an attempt has been made to evolve a set of factors influencing the entrepreneurial behaviour through a data reduction process of factor analysis. The factors include: planning orientation, work orientation, personal efficacy, market orientation, location, business acumen, dynamism, service orientation, in-depth knowledge, achievement motivation, social networks, interest, internal control, marketing strategy and innovativeness. The factor analysis brought out results that appeared to be in conformity with the existing theory of entrepreneurial motivation and entrepreneurial behaviour patterns of successful entrepreneurs.
\end{abstract}

Key words: Agripreneurship, determinants, entrepreneurship and factor analysis.

\section{INTRODUCTION}

The scheme on Agri Clinics and Agri Business Centers has been launched to enhance the quality of paid extension services to farmers in India. The scheme provides opportunities for self-employment to agricultural graduates in agricultural and allied enterprises mainly in the tertiary and secondary sectors (Small Farmers Agribusiness Consortium (SFAC, 2002). This scheme has been perceived to be double-edged as it envisages gainful employment to agricultural graduates in addition to providing quality extension services on payment basis to farmers. Parimaladevi, Husain and Bhaskaran (2006) reported that the most important factors influencing establishment of Agri Business units were attitude towards self-employment, entrepreneurial ability, and self-confidence. Dedicated personnel with managerial skills are a critical input for successful Agri Business (Arora, 2001). Hence, it has

\footnotetext{
${ }^{1}$ Corresponding author email: saka6186@gmail.com

${ }^{2}$ Principal Scientist, Division of Agricultural Extension, Indian Agricultural Research Institute, New Delhi.

${ }^{3} \mathrm{Ph}$. D. scholar, Division of Agricultural Extension, Indian Agricultural Research Institute, New Delhi
}

Received : 26.02.2012 
been felt imperative to the determinants of entrepreneurial behaviour through a data reduction process of the agripreneurs' responses of preferred rankings on several variables identified to be influencing the entrepreneurial behaviour and entrepreneurial success of Agri Clinic enterprises. Hence, Q-sort and factor analysis techniques were adopted to assess the determinants of entrepreneurial behaviour among agripreneurs'.

\section{METHODOLOGY}

The present study was conducted using an ex post facto research design. According to Kerlinger (1963) an ex post facto research is a systematic empirical enquiry in which the researcher does not have direct control over the variables because their manifestations have already occurred or because they are inherently not manipulable. The data were collected from the respondents through pre-tested structured interview schedule and analysed using statistical techniques.

\section{Locale of the study}

The scheme on Agri Clinics and Agri Business Centre (ACABC) implemented all over India was monitored and supervised by MANAGE (National Institute of Agricultural Extension Management). Key information on the performance of the scheme was collected by the researcher from MANAGE, which is the monitoring agency of Agri Clinic scheme. As per information available with MANAGE, huge response for Agri Clinic scheme came from Uttar Pradesh. The trained agricultural graduates were the highest (3586) in Uttar Pradesh and the number of Agri ventures opened was also the highest (1678) in same state. Hence, this state was purposively selected for the study.

\section{Selection of the Nodal Training Institute}

In Uttar Pradesh, seven centers were identified by MANAGE as Nodal Training Institutes (NTIs) to impart training for the participants of Agri Clinic scheme. All the Nodal Officers of these seven NTIs were personally contacted by the researcher, but only one nodal training institute, Sree Maa Guru Gramodyog Sansthan, Varanasi, evinced interest in the study and cooperated with the researcher. In fact all other nodal training institutes could not provide any information on the where abouts and contact address of their trainees under the ACABCs scheme. They did not have any follow-up activity with the trainees and did not possess any information on the progress of their Agri Clinic enterprises. So, Sree Maa Guru Gramodyog Sansthan, Varanasi, an NGO was considered for the study.

\section{Selection of Districts}

Under the NGO operated Nodal Training Institute, Sree Maa Guru Gramodyog Sansthan, Varanasi, the number of trained agricultural graduates (2006) as well as the number of Agri Clinics launched and running were the highest (1226). From this list, it was noted that the Agri Clinic operators were hailing from several agro-climatic 
zones and districts of Uttar Pradesh. Hence, five agro-climatic zones of Uttar Pradesh, viz., South-western semi-arid zone, western plains, central plains, eastern plains and Vindhyan zone were selected. From these five agro-climatic zones, twelve districts were selected purposively since these districts had successfully operating Agri Clinics. About 1-4 Agri Clinics were found in majority of districts. Since the nodal training institute was located in Varanasi, twelve Agri Clinics were successfully operating due to close supervision and hand holding support from the training institute.

\section{Selection of respondents}

From the twelve districts, the Agri Clinic operators, who were running their enterprises at the time of data collection, were selected as the respondents of the study. This sample consisted of Agri Clinic founders. A total of 40 Agri Clinic founders were chosen purposively from among those who were operating their Agri Clinics successfully for the last three years.

In order to get the preferences of the respondents on the collected list of variables, a Q-sort technique was used. Then the factor analysis was done on the 62 determinants using an exploratory approach, where the objective was to explore the possible underlying factor structure of a set of observed variables without imposing a preconceived structure on the outcome. The Q-sort technique was adopted for rank ordering the Agri Clinic entrepreneurs' perception of the entrepreneurial behavior. Most persons seem to enjoy sorting Q-decks perhaps because the method is both challenging and realistic. Hence, the Q-sort technique was adopted in the present investigation. In this technique, the subjects are required to sort the items into a number of categories each having in it a specified number of items as required to form a normal distribution. The categories are in rank order, the highest containing those items that are considered to be the most important and the lowest containing those items that are considered to be the least important. When the number of categories in the judgmental continuum is more, it provides more discrimination. But use of too many categories might lead to random judgment. Block (1961) emphasized that even though a nine point interval continuum makes a heavier demand on the judges, it elicits reliable discrimination. Kerlinger had also used a nine point judgmental continuum. Hence, in the present investigation it was decided to fix upon nine categories for the Q-sort distribution.

Before processing with factor analysis, 19 determinants were finally selected from the 62 determinants, after deleting those items which had the mean values less than median score i.e., 5.5. As stated by Comrey (1973) all the variables with factor loadings of 0.30 and above were considered as significant under each factor. All those variables, in each rotated factor that have high loadings were considered to be closely related variables. 


\section{RESULTS AND DISCUSSION}

The factor analysis was done on the Agri Clinic agripreneurs responses (preferred rankings) of 62 listed determinants influencing entrepreneurial behaviour of respondents. Q-sort technique was used to get the preferred rankings from the respondents. In the factor analysis, the principal component analysis was adopted and varimax rotation was used to draw a set of 19 factors. Based on the highest factor loading for each variable, the set of variables grouped under a factor were separated. Thus, at the end, fifteen factors have been identified and given appropriate names. All these results are presented below and discussed.

Table 1: Mean scores of preference rankings of determinants

\begin{tabular}{|l|l|l|}
\hline \multicolumn{1}{|c|}{ Variables included Q -sort technique } & $\begin{array}{c}\text { Mean } \\
\text { score }\end{array}$ & Degree of importance \\
\hline Capital & 8.00 & Highly important \\
Availability of technical information support & 7.80 & \\
\hline Planning & 7.30 & Very important \\
Self-confidence & 7.15 & \\
Hard work & 6.98 & \\
Strong training support & 6.78 & \\
\hline Determination & 6.35 & Quite important \\
Location & 6.15 & \\
Human relations & 6.15 & \\
Internal control & 6.10 & \\
Dedication & 6.07 & \\
Institutional support & 5.88 & \\
Commitment & 5.85 & \\
Work stress & 5.62 & \\
Interest & 5.50 & \\
\hline In depth knowledge & 5.48 & Some what important \\
Honesty & 5.45 & \\
Institutional linkage & 5.43 & \\
Business tactics & 5.40 & \\
Dynamism & 5.33 & \\
Decision making behaviour & 5.32 & \\
Promptness in delivery & 5.28 & \\
Goal setting tendency & 5.28 & \\
Personal efficacy & 5.28 & \\
Communication skills & 5.20 & \\
Service with smile & 5.18 & \\
Oral skills & 5.15 & \\
Responsiveness & 5.13 & \\
\hline
\end{tabular}




\begin{tabular}{|l|l|l|}
\hline \multicolumn{1}{|c|}{ Variables included Q -sort technique } & $\begin{array}{c}\text { Mean } \\
\text { score }\end{array}$ & Degree of importance \\
\hline Personal effort on outcomes & 5.10 & \\
Sincerity & 5.08 & \\
Self esteem & 5.07 & \\
Investment decisions & 5.05 & \\
Credibility & 5.03 & \\
Social networks & 5.00 & \\
Patience & 4.97 & \\
Self-Actualization & 4.97 & \\
Punctuality & 4.88 & \\
Marketing strategy & 4.85 & \\
Fairness & 4.85 & \\
Clear and forward looking & 4.83 & \\
Market Intelligence & 4.78 & \\
Achievement motivation & 4.65 & \\
Self-dependence & 4.65 & \\
Persuasability & 4.63 & \\
Readiness & 4.55 & \\
\hline Willingness to take challenge & 4.43 & Slightly important \\
Openness to feedback & 4.22 & \\
Role of values & 4.15 & \\
Tendency to take feedback & 4.13 & \\
Social support & 4.00 & \\
Unemployment among educated group & 4.45 & \\
Modernization & 3.70 & \\
Initiative & 3.50 & \\
\hline Need for commercial utilization of local & 3.43 & Of little importance \\
resources & 3.40 & \\
Change proneness & 3.38 & \\
Adoption propensity & 3.38 & \\
Price support & 3.33 & \\
Innovativeness & 3.18 & \\
Project management skill & 3.08 & \\
Creativity & 3.05 & \\
Autonomy & & \\
\hline Social disparity & 1.83 & Of very little importance \\
\hline
\end{tabular}

As can be seen from the above table, all the 62 were found to follow a normal distribution into seven categories. This indicates that the sample of respondents was found to represent the universe. The preferred rankings given by the respondents were put to factor analysis using a principal component analysis and varimax rotation 
of factors. Through these statistical procedures, a set of 19 factors were identified whose Eigen values were more than 1 . These Eigen values are given in table 2.

These Eigen values were found from principal component analysis. Results from the table 2 revealed that the variance explained by factor 1 is 7.346, which is about 11.85 per cent of total variance. Thus, all the 19 factors could explain 86.9 per cent of total variance among the selected 62 variables and their preferred ranking scores. The total variance explained is quite substantial and the factors identified were quite adequate.

Table 2: Eigen values of the principal components analysis

\begin{tabular}{c|cccc}
\hline \multirow{2}{*}{ Component } & \multicolumn{3}{|c}{ Initial Eigen values } \\
\cline { 2 - 4 } & Total & \% of Variance & Cumulative \% \\
\hline 1 & 7.346 & 11.848 & 11.848 \\
2 & 6.752 & 10.890 & 22.737 \\
3 & 4.764 & 7.683 & 30.420 \\
4 & 4.008 & 6.464 & 36.885 \\
5 & 3.537 & 5.704 & 42.589 \\
6 & 3.055 & 4.928 & 47.517 \\
7 & 3.022 & 4.875 & 52.392 \\
8 & 2.785 & 4.492 & 56.884 \\
9 & 2.594 & 4.183 & 61.067 \\
10 & 2.202 & 3.552 & 64.620 \\
11 & 2.090 & 3.372 & 67.991 \\
12 & 1.939 & 3.127 & 71.118 \\
13 & 1.758 & 2.836 & 73.955 \\
14 & 1.694 & 2.733 & 76.687 \\
15 & 1.544 & 2.490 & 79.178 \\
16 & 1.338 & 2.159 & 81.336 \\
17 & 1.240 & 2.000 & 83.336 \\
18 & 1.162 & 1.874 & 85.210 \\
19 & 1.050 & 1.694 & 86.905 \\
\hline
\end{tabular}

Extraction Method: Principal Component Analysis.

Further, these unrotated factors were rotated using an option of varimax rotation. This analysis gave rotated factors and their factor loadings. Factor loadings above 0.3 can be considered as significant. But to arrive at a final list of variables under each factor, the highest factor loading for each variable was considered and these were taken as the final factor loadings for all sixty two determinants. This 
exercise was done by comparing all the factor loadings of all 19 factors for each of 62 determinants. All these results can be seen in table 2, where only 15 factors were finally selected. These factors were truncated into a single column and given in table 3 , where the factors were also given a new name appropriate to set of variables.

Table 3: Factor loadings of the Factors identified and their names

\begin{tabular}{|c|c|c|c|}
\hline Factors & $\begin{array}{c}\text { Name assigned to } \\
\text { Factor }\end{array}$ & Determinants included in Factor Analysis & $\begin{array}{c}\text { Factor } \\
\text { Loadings }\end{array}$ \\
\hline \multirow[t]{11}{*}{1} & \multirow{11}{*}{$\begin{array}{l}\text { Planning } \\
\text { Orientation }\end{array}$} & Adoption propensity & 0.70268 \\
\hline & & Communication skills & 0.65079 \\
\hline & & Institutional support & 0.61324 \\
\hline & & Planning & 0.51057 \\
\hline & & Decision making behaviour & 0.44097 \\
\hline & & Openness to feedback & -0.44386 \\
\hline & & Investment decisions & -0.45515 \\
\hline & & Readiness & -0.55412 \\
\hline & & Social disparity & -0.58351 \\
\hline & & Honesty & -0.58868 \\
\hline & & Patience & -0.80328 \\
\hline \multirow[t]{16}{*}{2} & \multirow[t]{16}{*}{ Work Orientation } & Goal setting tendency & 0.77541 \\
\hline & & Project management skill & 0.61986 \\
\hline & & Need for commercial utilization of local resources & 0.59441 \\
\hline & & Modernization & 0.53928 \\
\hline & & Willingness to take challenge & 0.47286 \\
\hline & & Social support & 0.46690 \\
\hline & & Self-Actualization & 0.44686 \\
\hline & & Hard work & -0.42102 \\
\hline & & Personal effort on outcomes & -0.42778 \\
\hline & & Work stress & -0.50340 \\
\hline & & Determination & -0.54097 \\
\hline & & Institutional linkage & -0.55462 \\
\hline & & Commitment & -0.56895 \\
\hline & & Capital & -0.57268 \\
\hline & & Responsiveness & -0.61200 \\
\hline & & Punctuality & -0.66241 \\
\hline \multirow[t]{6}{*}{3} & \multirow[t]{6}{*}{ Personal Efficacy } & Unemployment among educated group & 0.61487 \\
\hline & & Persuasability & 0.52490 \\
\hline & & Personal efficacy & 0.52490 \\
\hline & & Strong training support & 0.51738 \\
\hline & & Human relations & 0.42987 \\
\hline & & Self-dependence & -0.47787 \\
\hline
\end{tabular}




\begin{tabular}{|c|c|c|c|}
\hline Factors & $\begin{array}{c}\text { Name assigned to } \\
\text { Factor }\end{array}$ & Determinants included in Factor Analysis & $\begin{array}{c}\text { Factor } \\
\text { Loadings }\end{array}$ \\
\hline \multirow[t]{6}{*}{4} & \multirow{6}{*}{$\begin{array}{l}\text { Market } \\
\text { Preparedness }\end{array}$} & Tendency to take feedback & 0.44573 \\
\hline & & Change proneness & 0.40182 \\
\hline & & Availability of technical information support & 0.39718 \\
\hline & & Market Intelligence & 0.30613 \\
\hline & & Sincerity & -0.52235 \\
\hline & & Self esteem & -0.60068 \\
\hline \multirow[t]{3}{*}{5} & \multirow[t]{3}{*}{ Location } & Location & -0.42119 \\
\hline & & Oral skills & -0.42912 \\
\hline & & Autonomy & -0.57478 \\
\hline \multirow[t]{6}{*}{6} & \multirow[t]{6}{*}{ Business Acumen } & Initiative & 0.51307 \\
\hline & & Dedication & 0.48700 \\
\hline & & Promptness in delivery & 0.48074 \\
\hline & & Business tactics & -0.45704 \\
\hline & & Creativity & -0.57736 \\
\hline & & Credibility & -0.57736 \\
\hline \multirow[t]{3}{*}{7} & \multirow[t]{3}{*}{ Dynamism } & Clear and forward looking & -0.46075 \\
\hline & & Dynamism & -0.49780 \\
\hline & & Fairness & -0.54866 \\
\hline \multirow[t]{2}{*}{8} & \multirow{2}{*}{$\begin{array}{l}\text { Service } \\
\text { Orientation }\end{array}$} & Price support & 0.51697 \\
\hline & & Service with smile & -0.50549 \\
\hline 9 & $\begin{array}{l}\text { In depth } \\
\text { knowledge }\end{array}$ & In depth knowledge & 0.46790 \\
\hline 10 & $\begin{array}{l}\text { Achievement } \\
\text { Motivation } \\
\end{array}$ & Achievement Motivation & -0.43613 \\
\hline \multirow[t]{2}{*}{11} & \multirow[t]{2}{*}{ Social networks } & Self-confidence & -0.37766 \\
\hline & & Social networks & -0.46191 \\
\hline \multirow[t]{2}{*}{12} & \multirow[t]{2}{*}{ Interest } & Role of values & -0.41585 \\
\hline & & Interest & -0.43107 \\
\hline 13 & Internal control & Internal control & -0.50542 \\
\hline 14 & $\begin{array}{l}\text { Marketing } \\
\text { strategy }\end{array}$ & Marketing strategy & 0.44505 \\
\hline 15 & Innovativeness & Innovativeness & 0.37430 \\
\hline
\end{tabular}

It was clear from the above table, only 15 factors were identified to have cluster of variables. While ten of the variables have a cluster of more than two variables, five factors have a single variable in them. All these 15 variables were independent of each other. This indicates that these factors have been achieved to represent the set of variables that were clustered together. Thus 15 factors were the final determinants for entrepreneurial behaviour of Agri Clinic agripreneurs of this study. These factors were not selected by choice but by statistical procedure. 


\section{DISCUSSION}

The approach of exploratory factor analysis was successfully done to yield a set of independent factors to represent the entrepreneurial behaviour and entrepreneurial success of Agri Clinic entrepreneurs. It was interesting to note that the planning orientation, work orientation, personal efficacy, market preparedness, and business acumen had the maximum number of variables clustered together. Location and dynamism had three variables each that were clustered together. The factors: in-depth knowledge, achievement motivation, innovativeness, internal locus of control, marketing strategy, interest, social networking, service orientation were found to be independently contributing to the successful entrepreneurial behaviour of the Agri Clinic agripreneurs.

\section{CONCLUSION}

The Q-sort technique and the factor analysis were found to be adequate and good tools for this sort of exploratory analysis of determinants of entrepreneurial behaviour among Agri Clinic and Agri Business agrirepreneurs. It may be concluded that the above 15 factors were found to be the determinants of entrepreneurial behaviour of Agri Clinic agrirepreneurs. These determinants of entrepreneurial behaviour could be useful for the entrepreneurial training centers, agencies helping to Agri Clinic and Agri Business entrepreneurs, planners and policy makers. The methodology used in deciding the determinants could be helpful for the social science researchers and students working in this area.

\section{REFERENCES}

Arora, V. P. S. 2001. Trade and employment opportunities in agribusiness. Agril. Ext. Rev., 13: 28-30.

Block, J. 1961. The Q-sort method in personality and psychiatric research. Charles C. Thomas Publisher, Springfield, U.S.A: Illions.

Comrey, A.L. 1973. A first course in factor analysis. Academic Press: New York and London.

Kerlinger, F.N. 1964. Foundations of Behavioral Research. Hort Rinehart and Winston, New York.

Parimaladevi, S. Sakeer Hussain, A. and Bhaskaran, S. 2006. Determinants of the effectiveness of the Agri Clinics and Agri Business centers scheme in Kerala. Journal of Tropical Agriculture 44 (1-2): 91-93.

SFAC. 2002. Agrientrepreneur. Technical Bulletin No.4, Small Farmers Agribusiness Consortium, Hyderabad. 